\title{
(2) OPEN ACCESS \\ Response: Methodological issue on prediction of emergency cesarean section by measurable maternal and fetal characteristics
}

\author{
Ping Guan, Fei Tang, Guogiang Sun, Wei Ren (1)
}

\section{Correspondence to} Dr Wei Ren, Department of Obstetrics, Maternal and Child Health Hospital of Hubei Province, Wuhan, Hubei Province, China; touga0201812@163.com

Accepted 1 May 2020 Published Online First 4 June 2020

\section{Linked}

http://dx.doi.org/10. 1136/jim-2020-001344

\section{Check for updates}

(C) American Federation for Medical Research 2020. Re-use permitted under CC BY-NC. No commercial re-use. Published by BMJ.

To cite: Guan P, Tang F, Sun $\mathrm{G}$, et al. J Investig Med 2020;68:1025

\section{Dear Editor,}

Thank you for the attention about our study. In this letter, we will answer the questions from the Letter to the Editor: Methodological issue on prediction of emergency cesarean section by measurable maternal and fetal characteristics. ${ }^{1}$ Some methodological issues have been proposed, such as the requirement of a cohort study, the identification of the optimal cut point and the effect of interactions among variables.

We must admit that although any retrospective study has some limitations compared with a prospective study, its clinical significance cannot be completely ignored. In fact, we have stated in the section of 'Materials and methods' that this study was a retrospective study, ${ }^{2}$ all data were real and can no longer be adjusted. We included all cases that met the criteria to avoid selection bias. Thus, this study did not include a cohort including failure and success subgroups actually, and other bias factors would not be avoided completely. Therefore, this study mainly analyzes the previous data and summarizes the clinical features of emergency cesarean section. In this study, all data were true, and the results and conclusions were reasonable. All variables showed clinical relevance with emergency cesarean section. We just analyzed the relationship between those variables and emergency cesarean section, then discussed the feasibility of establishing the prediction model based on the retrospective data.

In addition, the area under the curve can be used to survey the model's accuracy, and the prognostic ability of the risk prediction model and its scoring system could be evaluated with the receiver operating characteristic curve, too. ${ }^{34}$ Although dichotomy can reduce the reliability and applicability of model prediction in new patients, it is necessary to maintain certain clinical convenience as clinically related exploratory analysis, and complex a grouping method is not conducive to application. Thus, we finally chose the dichotomy during the process of optimal cut point identification.

The current study was only concluded based on the results of retrospective data, the model has not been strictly clinical design and validation by another study, and was not used in any current clinical setting. We do agree with the authors, that any conclusions on these fields should be supported by rational methods and validated by another study. Thus, we also recognized the limitations of this study in the 'Discussion' section. Actually, we have declared in the paper that we would look forward to carrying out prospective studies to verify the results of this study in the future. We will carry out a prospective study with reasonable design, strictly inclusion criteria and grouping methods to control the confounding factors, and improve the methods. We also welcome other studies to verify the correctness and clinical applicability of this conclusion.

Contributors All authors: manuscript writing.

Funding The authors have not declared a specific grant for this research from any funding agency in the public, commercial or not-for-profit sectors.

Competing interests None declared.

Patient consent for publication Not required.

Provenance and peer review Commissioned; internally peer reviewed.

Open access This is an open access article distributed in accordance with the Creative Commons Attribution Non Commercial (CC BY-NC 4.0) license, which permits others to distribute, remix, adapt, build upon this work non-commercially, and license their derivative works on different terms, provided the original work is properly cited, an indication of whether changes were made, and the use is non-commercial. See: http://creativecommons.org/licenses/ by-nc/4.01.

ORCID iD

Wei Ren http://orcid.org/0000-0003-2573-8469

\section{REFERENCES}

1 Guan $\mathrm{P}_{\text {, Tang }}$, Sun G, et al. Prediction of emergency cesarean section by measurable maternal and fetal characteristics. $J$ Investig Med 2020;68:799-806.

2 Abbasi M, Naderi M. Methodological issue on prediction of emergency cesarean section by measurable maternal and fetal characteristics. J Investig Med 2020;68:1025.

3 Cai Q-C, Yu E-D, Xiao Y, et al. Derivation and validation of a prediction rule for estimating advanced colorectal neoplasm risk in average-risk Chinese. Am J Epidemiol 2012;175:584-93.

4 Moons KGM, Harrell FE, Steyerberg EW. Should scoring rules be based on odds ratios or regression coefficients? I Clin Epidemiol 2002:55:1054-5. 